\title{
Geology and geomorphology of the Cappadocia volcanic Province, Turkey
}

\author{
Catherine Kuzucuoğlu ${ }^{1}$
}

Published online: 20 December 2019

C) Springer Nature Switzerland AG 2019

Throughout historical time, the region of Cappadocia has occupied a geographic position that has made this land an essential member of the geologic, environmental, as well as human network enlivening the Eastern Mediterranean basin. As a result, the definition of the "Cappadocia" as a region depends on the type, characteristics and origin of landscapes one has in mind, as well as on the time interval concerned.

The word "Katpatuka" seems to go back to a Hittite toponym, transformed into "Cappadocia" at a time as far back as the sixth century BC. According to Herodotus, this "Cappadocia" extended from the Taurus Mountains in the south to the Black Sea north of the Pontus region, and was bound to the west by Lycaonia (i.e. the west-central part of Anatolia, where today's city of Konya is located), and to the northwest by Galatia (today the regions of Bolu, Ankara, Çorum and Yozgat). On the other hand, touristic information leaflets and books praising "Cappadocia" refer to a small region confined between the cities of Nevşehir, Niğde and Kayseri (formerly the Hattian Mazaca, then Eusebia at the Argaeus and, finally Caesarea), the Roman Capital City of Cappadocia. This area, which attracts millions of visitors per year, possesses a high density of peculiar landscapes combining specific natural landforms (badlands, canyons and fairy chimneys, e.g. Sarıkaya et al. 2015a) and humansculpted troglodytic landforms (caves, dwellings, churches and settlements) recording a long history of occupation since antiquity (Özbaşaran 2011; Özbaşaran et al. 2018; Mouralis et al. 2019a; Çiner and Aydar 2019). These historical and touristic territorial dimensions of "Cappadocia" superimpose another dimension drawn by a unique geological and geomorphological territory whose evolution is deeply rooted in the last 15 million years.

Catherine Kuzucuoğlu

catherine.kuzucuoglu@lgp.cnrs.fr

1 Laboratory of Physical Geography (LGP, UMR 8591), Paris

1 University and CNRS, Meudon, France
This geological region, wider than the touristic one and smaller than the historical one, presents specific geological structures and geomorphological landscapes dominated by volcanic and tectonic processes that commenced during the middle Miocene, $c .15$ million years ago (Dewey and Şengör 1979; Şengör and Y1lmaz 1981; Aydar et al. 2012). In this context, an energetic magmatic activity produced groups of geological and geomorphological features, creating a high variety of volcanic destruction and accumulation forms, intermingled with active tectonics controlling a maze of small to wide basins dispersed in the region (e.g. Dhont et al. 1998; Koçyiğit and Beyhan 1998; Sarıkaya et al. 2015b). River and slope (deep and superficial) erosion responding to geologic (rock resistance vs uplift vs volcanic dams) as well as climatic (hydrology vs precipitation) forcing superimposed varied shapes onto the volcanic substrate. The boundaries of this "Cappadocia" thus draw a large region of roughly square shape limited (1) to the north, by the Kizılırmak (the classical Halys) River valley where Avanos city is located; (2) to the west by the Tuz Lake (Salt Lake) basin, on the eastern side of which the town of Aksaray is located; (3) to the south, the W-E alignment of Hasandağ, Keçiboyduran and Melendiz volcanoes, at the eastern end of which the city of Niğde is located; (4) to the east, to the rectilinear cliffs of the Cappadocian plateau reaching the Sultansazlığ 1 Plain and the Erciyes Volcano at the foot of which the city of Kayseri was founded.

Within these boundaries, the present issue contains several articles concerning two important aspects of the evolution of the geological, geomorphological and biological features that took and still take part in forming and constructing today's Cappadocia. The articles of this special issue concern two broad topics: (1) palaeoenvironments (see papers by Doğan et al. 2019; Gürbüz et al. 2019; Tuncer et al. 2019), and (2) processes and consequences of magmatic activity and their relationships with the evolution of the volcanic landscapes through time and space (see papers 
by Atici et al. 2019; Aydemir et al. 2019; Ersoy et al. 2019; Kuzucuoğlu et al. 2019; Mouralis et al. 2019b).

With a synthetic presentation of geological data from sedimentary deposits and paleontological remains recording past environments and climates in Cappadocia, Gürbüz et al. (2019) and Doğan et al. (2019) characterize several phases of depositional environments in the region. Their analyses of lithofacies, fossil mammal and pollen contents point to three terrestrial packages recording lacustrine and fluvial, highly dynamic environments. During the middle Miocene, landscapes included lakes and continental environments characterized by braided river deposits. During the late Miocene/early Pliocene the construction of flood plains interacted with contracting lakes, at the same time as volcanic products started to interfere and intermingle with the ongoing sedimentation. During the Pleistocene, lacustrine and continental depositional environments similar to the Neogene ones continued to be filled-in forming large Pleistocene sedimentary basins and riverbeds controlled by active faults. Regarding the biological aspects of the landscapes, middle Miocene sedimentary series record a highly humid climate sustaining flourishing arboreal landscapes. The regression of taxa pertaining to these forests at the beginning of late Miocene indicates a drying climate trend, which is also confirmed by mammal and pollen fossil content of Mio-Pliocene sedimentary and volcanoclastic units. In the meantime, regional tectonics driven by continental collision between the Eurasian and Arabian continents in Eastern Anatolia (Dhont et al. 1998; Koçyiğit and Beyhan 1998; Şengör et al. 2008) caused a dramatic diversification of the fauna in Cappadocia.

While the early Pleistocene environmental evolution remains little known (Gürbüz et al. 2019), the geomorphology and geology of this period are studied by Doğan et al. (2019). These authors integrate both the sedimentological records of lake/river deposits and their tectonic deformations, documenting a drainage system organized and developed since the beginning of Pleistocene until today. They list five river terraces older than the Holocene that record different climatically or tectonically driven dynamics (Kuzucuoğlu et al. 2018). Thanks to sedimentary sequences cored in lakes and marshes, Holocene records have increased during the last 2 decades. They clearly show the dominance of arboreal taxa during the early Holocene followed by a drying trend during the late Holocene (Woldring 1997; Woldring and Bottema 2001/2002). Within this frame, the results of the study of ostracod successions at Eski Acıgöl crater by Tuncer et al. (2019) provide precision on the timing and characterisation of the environmental conditions recorded by the crater-fill. In the lower third of the sequence, these conditions define an early wet climate characterized by freshwater to oligohaline, oligotrophic and relatively deep lacustrine conditions alternating with short lake shrinkage intervals. This early Holocene phase is interrupted by a climatic switch ending, in saline, shallow and warmer lacustrine conditions recorded in the two upper thirds (Roberts et al. 2001; Dean et al. 2017). The rather high resolution of this Holocene sequence allows documenting that, during the last millennia, the role of anthropogenic factors in changing the natural environmental records has increased.

In addition to tectonics, climate and fluvial incision (Çiner et al. 2015), the regional volcanic activity since the Miocene and Pliocene must also be taken into account when reconstructing the origin and evolution of the current landscapes of Cappadocia (e.g. Le Pennec et al. 1994, 2005; Aydar and Gourgaud 1998; Froger et al. 1998; Mouralis et al. 2002; Aydar et al. 2012), especially during the Pleistocene (Kuzucuoğlu et al. 1998; Reid et al. 2017; DoğanKulahc1 et al. 2018). While demonstrating the capacity of the region to possess high hot dry rock (HDR) energy potential, i.e. making it possible to construct high and efficient geothermal energy plants in the future, Aydemir et al. (2019) also present a general regional heat flow map. In their specific research on eruption processes and phasing, Ersoy et al. (2019) reconstruct the various explosive phases that have accompanied the extrusion of the Dikkartın dome on the southern slopes of the Erciyes stratovolcano c. $9.5 \mathrm{ka}$ ago (Sarıkaya et al. 2019). These results underline the role of water content and phase (from vapour to humidity condensation into water) in controlling the eruption progression.

In line with researches concerning recent volcanic topics in Cappadocia (e.g. Aydın et al. 2014; Reid et al. 2017; Doğan-Kulahcı et al. 2018), three articles in this special issue provide new and important data concerning the middle to late Pleistocene bimodal volcanic activity in "Cappadocia". These articles focus on (1) two rhyolitic complexes, the middle Pleistocene Göllüdağ (Mouralis et al. 2002; Mouralis et al. 2019b) and the mid-late Pleistocene Acıgöl caldera (Druitt et al. 1995; Mouralis et al. 2002; Atici et al. 2019; Mouralis et al. 2019b), the latter also containing basaltic volcanoes, and (2) the Hasandağ stratovolcano (Aydar and Gourgaud 1998; Kuzucuoğlu et al. 2019). In the frame of these three articles, new dates on Göllüdağ domes (K/Ar), Acıgöl caldera (zircons) and Hasandağ stratovolcano (K/ Ar) are presented, while preliminary results from chemical and mineralogical analyses are presented as complementary material for the integration in international databases about worldwide volcanism.

In conclusion, this special issue on Cappadocia in Turkey enlightens the role of tectonics and climate in the formation of the current landscapes of a region framed by volcanic events that constructed and destroyed outcrops and landforms. The active role of volcanism, tectonism and climate in shaping the Cappadocian landscapes continue. As a result, today's landscapes in Cappadocia mix stratovolcanoes and deeply incised canyons, volcanic flows and 
tectonic fault lines, maar lakes and basaltic cones, mesas over plateaus incised by dry valleys covered with tephras, travertines underlining heat conduits controlled by fault systems. Several articles in this issue stress the continuation of tectonic (Doğan et al. 2019), magmatic (Aydemir et al. 2019; Kuzucuoğlu et al. 2019), volcanic (Atici et al. 2019; Ersoy et al. 2019; Kuzucuoğlu et al. 2019; Mouralis et al. 2019b), and climatic (Doğan et al. 2019; Tuncer et al. 2019) impacts not only landscapes but also the future of the region and of its population.

\section{References}

Atici A, Schmitt AK, Friedrichs B, Sparks S, Danišík M, Yurteri E, Gündoğdu EA, Schindlbeck-Belo J, Çobankaya M, Wang K-L, Lee H-Y (2019) Ages and glass compositions for paired largevolume eruptions from the Acigöl volcanic complex. Med Geosc Rev, Cappadocia (Turkey). https://doi.org/10.1007/s42990-01900013-5

Aydar E, Gourgaud A (1998) The geology of Mount Hasan stratovolcano, central Anatolia, Turkey. J Volcanol Geothermal Res 85:129-152. https://doi.org/10.1016/S0377-0273(98)00053-5

Aydar E, Schmitt AK, Çubukçu HE, Akın L, Ersoy O, Şen E, Duncan RA, Atici G (2012) Correlation of ignimbrites in the central Anatolian volcanic province using zircon and plagioclase ages and zircon compositions. J Volcanol Geother Res 213-214:83-97. https://doi.org/10.1016/j.jvolgeores.2011.11.005

Aydemir A, Bilim F, Kosaroglu S, Buyuksarac A (2019) Thermal structure of the Cappadocia Region, Turkey: a review with geophysical methods. Med Geosci Rev. https://doi.org/10.1007/s42990-01900011-7

Aydın F, Schmitt AK, Siebel W, Sönmez M, Ersoy Y, Lermi A, Dirik K, Duncan R (2014) Quaternary bimodal volcanism in the Niğde Volcanic Complex (Cappadocia, central Anatolia, Turkey): age, petrogenesis and geodynamic implications. Contrib Mineral Petr 168:1078-1102

Çiner A, Aydar E (2019) A fascinating gift from volcanoes: the fairy chimneys and underground cities of Cappadocia. In: Kuzucuoğlu C, Çiner A, Kazancı N (eds) Landscapes and landforms of Turkey. Springer Publ, World Geomorphological Landscape, pp 534-549

Çiner A, Doğan U, Yıldırım C, Akçar N, Ivy-Ochs S, Alfimov V, Kubik PW, Schlüchter C (2015) Quaternary uplift rates of the Central Anatolian Plateau, Turkey: Insights from cosmogenic isochronburial nuclide dating of the Kiz1lırmak River terraces. Quat Sci Rev 107:81-97. https://doi.org/10.1016/j.quascirev.2014.10.007

Dean JR, Jones MD, Leng MJ, Metcalfe SE, Sloane HJ, Eastwood WJ, Roberts CN (2017) Seasonality of Holocene hydroclimate in the Eastern Mediterranean reconstructed using the oxygen isotope composition of carbonates and diatoms from Lake Nar, central Turkey. Holocene. https://doi.org/10.1177/0959683617721326

Dewey JF, Şengör AMC (1979) Aegean and surroundings regions: complex multiplate and continuum tectonics in a convergent zone. Geol Soc Am Bull 90:84-92

Dhont D, Chorowicz J, Yürür T, Froger JL, Köse O, Gündoğdu N (1998) Emplacement of volcanic vents and geodynamics of Central Anatolia, Turkey. J Volcan Geotherm Res 85:33-54

Doğan U, Koçyiğit A, Yılmaz E (2019) Geomorphological evolutionary history of the Melendiz River Valley. Med Geosc Rev, Cappadocia, Turkey. https://doi.org/10.1007/s42990-019-00012-6
Doğan-Kulahcı GD, Temel A, Gourgaud A, Varol E, Guillou H, Deniel C (2018) Contemporaneous alkaline and calc-alkaline series in Central Anatolia (Turkey): Spatio-temporal evolution of a post-collisional Quaternary basaltic volcanism. J Volcanol Geotherm Res 156:56-74

Druitt TH, Brenchley PJ, Gökten YE, Francaviglia V (1995) Late quaternary rhyolitic eruptions from the acigöl complex, central Turkey. J Geol Soc 152:655-667

Ersoy O, Aydar E, Şen E, Gourgaud A (2019) Contrasting fragmentation and transportation dynamics during the emplacement of Dikkartın rhyodacitic dome; Erciyes stratovolcano, central Turkey. Med Geosc Rev. https://doi.org/10.1007/s42990-01900014-4

Froger J-L, Lénat J-F, Chorowicz J, Le Pennec J-L, Bourdier J-L, Köse O, Zimitoğlu O, Gündoğdu NM, Gourgaud A (1998) Hidden calderas evidenced by multisource geophysical data; example of Cappadocian Calderas, Central Anatolia. J Volcanol Geotherm Res 185:99-128

Gürbüz A, Saraç G, Yavuz N (2019) Paleoenvironments of the Cappadocia region during the Neogene and Quaternary, central Turkey. Med Geosc Rev. https://doi.org/10.1007/s42990-019-00016-2

Koçyiğit A, Beyhan A (1998) A new intracontinental transcurrent structure: the central anatolian fault zone. Turkey, Tectonophysics 284:317-336

Kuzucuoğlu C, Dumoulin J-P, Saulnier-Copard S (2018) Geomorphological and palaeoenvironmental setting of Aşıklı Höyük. In: Özbaşaran M, Duru G, Stiner M (eds) The early settlement at Aşıklı Höyük. Ege Yay. Publ, Istanbul, pp 15-42

Kuzucuoğlu C, Gündoğdu Atakay E, Mouralis D, Atıcı G, Guillou H, Türkecan A, Pastre J-F (2019) Geomorphology and tephrochronology review of the Hasandağ volcano (Southern Cappadocia, Turkey). Med Geosc Rev. https://doi.org/10.1007/s42990-01900017-1

Le Pennec JL, Bourdier JL, Froger JL, Temel A, Camus G, Gourgaud A (1994) Neogene ignimbrites of the Nevşehir Plateau Central Turkey: stratigraphy, distribution and source constraints. J. Volcanol. Geotherm. Res. 63(1-2):59-87

Le Pennec JL, Temel A, Froger JL, Şen S, Gourgaud A, Bourdier J-L (2005) Stratigraphy and age of the Cappadocia ignimbrites, Turkey: reconciling field constraints with paleontologic, radiochronologic, radiochronologic, geochemical and paleomagnetic data. J. Volcanol. Geotherm. Res. 141:45-64

Mouralis D, Pastre J-F, Kuzucuoğlu C, Türkecan A, Atıcı Y, Slimak L, Guillou H, Kunesch S (2002) The Quaternary rhyolitic complexes of Central Anatolia (Göllü Dağ and Acıgöl, Turkey): formation, instability, and environmental constraints. Quaternaire 13:219_ 228 (in French)

Mouralis D, Aydar E, Türkecan A, Kuzucuoğlu C (2019a) Quaternary Volcanic Landscapes and Prehistoric Sites in Southern Cappadocia: Göllüdağ, Acıgöl and Hasandağ. In: Kuzucuoğlu C, Çiner A, Kazancı N (eds) Landscapes and landforms of Turkey. Springer, Berlin, pp 551-563

Mouralis D, Pastre J-F, Kuzucuoğlu C, Türkecan A, Guillou H (2019b) Tephrostratigraphy and chronology of the Quaternary Göllüdag and Acıgöl volcanic complexes (Central Anatolia, Turkey). Med Geosc Rev. https://doi.org/10.1007/s42990-019-00010-8

Özbaşaran M (2011) The Neolithic on the Plateau. In: Steadman SR, McMahon G (eds) Ancient Anatolia 10,000-323 B.C.E. The Oxford Handbook of Ancient Anatolia. Oxford University Press, Oxford, pp 99-124

Özbaşaran M, Duru G, Stiner M (eds) (2018) The Early Settlement at Așıklı Höyük, Essays in Honor of Ufuk Esin. Ege Yay, Istanbul

Reid MR, Schleiffarth WK, Cosca MA, Delph JR, Blichert-Toft J, Cooper KM (2017) Shallow melting of MORB-like mantle under hot continental lithosphere, Central Anatolia. Geochem Geophys Geosyst. https://doi.org/10.1002/2016GC006772 
Roberts N, Reed J, Leng M, Kuzucuoğlu C, Fontugne M, Bertaux J, Woldring H, Bottema S, Black S, Hunt E, Karabiyıkoğlu M (2001) The tempo of Holocene climatic change in the Eastern Mediterranean region: a new high-resolution crater-lake sediment data from central Turkey. Holocene 11(6):721-736

Sarıkaya MA, Çiner A, Zreda M (2015a) Fairy chimney erosion rates on Cappadocia ignimbrites, Turkey: insights from cosmogenic nuclides. Geomorphology 234:182-191. https://doi.org/10.1016/j. geomorph.2014.12.039

Sarıkaya MA, Yıldırım C, Çiner A (2015b) Late Quaternary alluvial fans of Emli Valley in the Ecemiş Fault Zone, south central Turkey: Insights from cosmogenic nuclides. Geomorphology 228:512-525. https://doi.org/10.1016/j.geomorph.2014.10.008

Sarıkaya MA, Çiner A, Zreda M, Şen E, Ersoy O (2019) Chlorine degassing constrained by cosmogenic ${ }^{36} \mathrm{Cl}$ and radiocarbon dating of early Holocene rhyodacitic lava domes of Erciyes Stratovolcano, central Turkey. J Volcanol Geother Res 369:263-275

Şengör AMC, Y1lmaz Y (1981) Tethyan evolution of Turkey: a plate tectonic approach. Tectonophysics 75:181-241. https://doi. org/10.1016/0040-1951(81)90275-4

Şengör AMC, Özeren MS, Keskin M, Sakınç M, Özbakır AD, Kayan İ (2008) Eastern Turkish high plateau as a small Turkic-type orogen: implications for post-collisional crust-forming processes. Earth Sci Rev 90:1-48. https://doi.org/10.1016/j.earth scirev.2008.05.002

Tuncer A, Tunoğlu C, Aydar E, Yılmaz İÖ, Gümüş BA, Şen E (2019) Holocene paleoenvironmental evolution of the Acıgöl paleo maar lake (Nevşehir. Med Geosc Rev, Central Anatolia). https://doi. org/10.1007/s42990-019-00009-1

Woldring H (1997) Late Glacial and Holocene vegetation history of Central Anatolia: the palynological record of Eski Acigöl. Abstracts of the Regional INQUA Symposium on Late Quaternary in the Eastern Mediterranean, Ankara, Turkey, April

Woldring H, Bottema S (2001/2002) The vegetation history of EastCentral Anatolia in relation to Archaeology: The Eski Acigol pollen evidence compared with the Near Eastern environment. Palaeohistoria 44:1-34

Publisher's Note Springer Nature remains neutral with regard to jurisdictional claims in published maps and institutional affiliations. 